\title{
The Encouragement of Teacher's Descriptive Notes in Student Report Card
}

\author{
Aloysius Mering ${ }^{1}$, Indri Astuti ${ }^{2}$, Fadillah $^{3}$ \\ ${ }^{1}$ Education Evaluation, Tanjungpura University, Indonesia \\ Email: mering7157@yahoo.co.id \\ ${ }^{2}$ Educational Tecnology, Tanjungpura University, Indonesia \\ Email: indrifkipuntan@gmail.com \\ ${ }^{3}$ Educational Tecnology, Tanjungpura University, Indonesia \\ Email: fadillah@gmail.com
}

(Received: January-2019; Reviewed: February-2019; Accepted: March-2019; Published: April-2019)

(7) (8) C2019 - EST Graduate Program Universitas Negeri Makassar. This is an article with open access under license CC BY-NC-4.0 (https://creativecommons.org/licenses/by-nc/4.0/ ).

\begin{abstract}
This study aimed to (a) describe aspects in descriptive notes that teachers do on student report cards, $(b)$ describe the efforts of teachers in making descriptive notes on student report cards, and (c) examine the teacher's encouragement power in descriptive notes on report cards against students. The research information was obtained through survey method towards teachers, students, and parents in Gembala Baik Senior High School, SantunUntan Senior High School, and Senior high school in Sukadana, Kayong Utara district, in the form of questionnaire, interview, and documentation. From the result of the study it could be explained that teachers have written the aspects of knowledge, skills, and attitudes in student report cards balanced in the descriptive record, the teacher mentioned: the name of the student, behavior, things that need improvement, attitude, saying "congratulations", avoiding negative labels, and encouraging words. In addition, "Some teachers" let the application provided to make the descriptive notes. Moreover, only "a small part" of the teacher who was convinced that the notes have encouraged students actually. Therefore, the descriptive notes was "less effective".
\end{abstract}

Keywords:descriptive notes; report cards; encouragement.

\section{INTRODUCTION}

The curriculum 2013 requires teachers to make descriptive notes on student report cards. Arief Rachman (Ukim Komarudin, 2015: 72) calls it a qualitative report card. Qualitative report cards or qualitative records are records of students' character development in learning at school. Qualitative report cards (descriptive notes) made by the teacher narratively on student report cards are an effort to complete the learning outcome information so that each student is motivated to progress. According to Semi in (Panjaitan, 2015), narrative is a conversation or writing that aims to convey or tell a series of events from time to time.

Furthermore, Arief Rachman called it
"Encouragement". Encouragement can be interpreted as encouragement, encouragement, or something encouraging (Hornby, 1995). In other terms it can be interpreted as a stimulant, which is something that becomes a whip for improving achievement or morale (learning, etc.); driver(Depdiknas, 2000). Research conducted by (Claessens et al., 2016) showing that a positive relationship between teachers and students can influence learning activities. If it is related to the results of study that children, on average received $460(86 \%)$ negative comments or criticism and 75 (14\%) positive comments or support every day, the teacher's descriptive notes on student report cards could have a positive impact or negative (Canfield, 1990). Jack Canfield (1990) also said that continuous negative feedback is very 
dangerous because it causes "learning stagnation". (Abrar et al., 2018) also stated that negative comments from teachers can also prevent students from being active in learning. This study used the word encouragement as a useful indicator (effectiveness) of the teacher's descriptive notes on student report cards. The review of the power of encouragement of the teacher's descriptive record will be seen mainly from the side of the teacher, students, and parents of students.

About the procedures for evaluating students in schools that use the curriculum 2013 is regulated in the Regulation of the Minister of Education and Culture (Permendikbud) No. 23 of 2016 (regarding Educational Assessment Standards). In the Minister of Education and Culture, assessment of learning outcomes includes assessment of attitudes, knowledge, and skills. Attitude assessment is carried out through stages; (a) observe the behavior of students during learning, (b) record the behavior of students using the observation / observation sheet, (c) follow up on the results of observations; and (d) describe the behavior of students. Attitude assessment is an activity carried out by the teacher to obtain descriptive information about the behavior of students. The peculiarity of the assessment in the curriculum 2013 is the need to do and report descriptive information about the attitudes of students in report cards.

Descriptive notes will be effective if the teacher provides written and verbal support to improve students' self-motivation to learn. The teacher does not teach but prepares a good learning environment for students. Giving a positive vocabulary "let's do it" "do it, continue to find it finally", "keep your performance awake". The impact of providing teacher support, children become confident, empathy, expectations and self-actualization (Joyce \& Early, 2014). According to humanistic learning theory, human nature has a strong urge to achieve more than a safe and static existence. This basic tendency to reach the highest potential even when faced with internal and external obstacles will still be carried out. Humanistic ideas can be summarized as follows: (1) everyone has the capacity to develop; (2) everyone has the freedom to choose their life goals; (3) emphasizing the quality of life; (4) everyone has the ability to improve their quality of life; (5) everyone has a positive self-image and good self-understanding; (6) self-actualization is an encouragement to develop full potential as individuals (Corey,
2011)

According to Jacobs (2012) the skill of giving verbal touch psychologically is the basic skill of a teacher who must be mastered in helping students. According to (Walberg \& Greenberg, 1997) the social environment is the main psychological determinant that influences academic learning. Research showed that the quality of relationships with teachers is the most important factor in relation to comfort in learning or not (Hagenauer, Hascher, \& Volet, 2015). The creation of social relations through the descriptive notes of the right teacher is expected to be able to bring positive emotions to students in learning. The teacher's job is to teach, educate, train and guide. For that according to scaffolding design, teachers should design learning using the 5 C model, namely: communication, collaboration, control, creativity, consistency (James, 2010). Through communication, students learn about listening, observation, thinking and speaking. Collaboration builds teacher involvement and parents' commitment (Povey et al., 2016). Control by building no punishment, commitment and accepting the consequences of his actions. Creativity with teachers is not discriminatory, respecting each student's progress. Consistency with the demands of providing descriptive support and hope for change is easy for students. Scaffolding is a mechanism for providing support to help students take responsibility according to developmental tasks in the proximal developmentzone so that they have the opportunity to resolve independently (Slavin, 2009; Belland, 2014; Belland, B. R., Walker, A. E., Olsen, M. W., \& Leary, 2015; Lin, T. C., Hsu, Y. S., Lin, S. S., Changlai, M. L., Yang, K. Y., \& Lai, 2012).

The right teacher description is a learning process for students who can motivate themselves to be more academically advanced. All the knowledge we obtain is the result of our own construction (Gagnon \& Collay, 2001). The role of the teacher is the learning designer (Prawiradilaga, 2004). One of the teacher's roles is to design teacher's description notes in report cards that can be measured and carried out by students. Collaboration between teachers and parents should be carried out to realize teacher records. Megawangi (2004) explains that parenting is the process of creating an atmosphere of teaching and learning activities emphasizing towards warmth rather than towards emotions. Parenting is the best way for parents to educate children as a manifestation of a sense of 
responsibility to the development of children's education (Ceka \& Murati, 2016). For parents, report card comments can gradually "distract" them from the row of numbers and also the child's ranking. Admittedly or not, until now the majority of parents in Indonesia still emphasize the value obtained by children and also compare the abilities of children with their friends. Well, the narrative written by the teacher can change their paradigm that not only symbolic numbers need to be considered, but also the attitude of learning and also the ability of socialization, creativity, and other aspects. While for the teacher, the comments he wrote could be a means of reflection to what extent the learning and guidance he provided had succeeded in increasing the development of his students (Nicol, 2010). As with parents, the comments can also remind the teacher again to pay attention to the development of students in a holistic manner (Mona, 2012).

In reality, this descriptive assessment is left to the application (computer system), not done by the subject teacher or homeroom teacher. According to LJ (Gembala baik High School Teacher, 2018), this was due to the large number of subjects, basic competencies, indicators, and the number of students to be noted.

In the Curriculum 2013, the Director General of Primary and Secondary Education, Hamid Muhammad mentions the difficulties faced by teachers in evaluating student learning outcomes, among others; (1) there are still many teachers who experience difficulties in assessing spiritual attitudes (KI-1) and social attitudes (KI$2),(2)$ there are still many teachers who are not accustomed to using several assessment techniques, such as portfolios and projects in conducting skills assessments, (3) schools have difficulty in determining the interval of the predicate of knowledge and skills that refers to KKM for the minimum limit of C, and (4) understanding and implementation of remedial in schools are still many different perceptions. The portfolio for assessment is the main factor that is very suitable for authentic assessment, assessing student performance according to its potential (Baird, Gamble, \& Sidebotham, 2016). Furthermore, Dalman (2015) said that writing is basically a skill to record thoughts into written form using a particular system so that the message written by the teacher in report cards can be understood by students.

Recognizing the difficulty of filling out these descriptive values, the government provides tutorial videos, for example for elementary schools. However, the teacher (LJ, Thursday, April 26, 2018) explained that filling out descriptive notes on student report cards was "difficult and complicated." Especially if the writing was tailored to the unique needs of individual students is a psychological aspect that can encourage someone to do something is "motivation" (Maslow, 2013). The accuracy of teachers in providing support to students can examine the potential of students, according to the opinion of Vigotsky (Astuti, 2015) says education provides an impact in developing to improve knowledge, skills and competencies. The high school simplifies the applications provided by the government and makes "machine" applications for descriptive records of student report cards to make it easier. Carried out continuous studies to develop themselves, this is in accordance with the education technology area, namely "Studies (studies) and ethics-based practices in facilitating learning and improving performance by creating, using, and managing appropriate technological and resource processes (AECT in Pribadi, 2018).

From the description of the background of the research above this study will focus on "how much power the descriptive record of the teacher on the student report card influences students to make improvements according to the notes".

\section{METHOD}

This research is survey research, because it will get information from schools, teachers, students, and parents who are selected by area sampling, aiming, and stratified techniques.

The stages of determining respondents are determining (1) area (district / city), (2) school, (3) class, (4) teacher, (5) students, and (6) parents of students. Of the 14 districts / cities, researchers chose the city of Pontianak as a district / city representative whose education was "advanced" and North Kayong District representing districts / cities that were only 11 years of age (districtexpansion in 2007). The selection of schools is based on the accreditation category (Gembala baik High School "A" and High School Santun Untan "B). Furthermore, after setting the respondent's school, the classes surveyed are classes X, XI, and XII. The number of respondent students is set at 20 people in grade 
level or around 60 students per school. The teacher and parents of the respondents are determined by the respondent's school. Especially parents of students are parents of students who are also determined as respondents. From the criteria for determining respondents obtained total respondents, 158 students, 143 parents of students, and 69 teachers.

The instrument used consisted of an assessment questionnaire from students, teachers, and parents. Students and parents got the same questionnaire, which was 48 response items, but there were adjustments to the editorial. Instruments for teachers are constructed separately with 58 items of response.

The research instrument covers aspects of encouragement records. The category of effective encouragement - ineffective in encouraging students. The characteristics of students motivated to make changes by the teacher's descriptive notes are (1) students read and understand the teacher's notes and (2) change actions according to the teacher's descriptive notes. Student assessments are obtained by questionnaires or discrete scales of "appropriate" - "inappropriate" and continuum scales. The main questions in the instrument are (a)whether students read the teacher's descriptive notes, (b) students understand the teacher's descriptive notes, (c) whether the teacher's notes correspond to the problems experienced by students in accordance with quantitative values or numbers printed on report cards, (d) whether the teacher's notes give rise to enthusiasm or desire to improve themselves, and (e) have there been actions students have improved themselves

Data analysis used descriptive statistical procedures (mean and presentation). Average and percentage analysis to determine the relative number of respondents who responded (answered) certain items. Thus it can be concluded that the number of respondents who gave the same or different opinion on an item. In addition, it is interesting to analyze the level of relations ( $\mathrm{r}$ product moment) between the response of students and parents and different tests (with t-test) between parents and between students from the school that is the location of the respondents.

\section{RESULT AND DISCUSSION}

\section{Result}

This research is about to reveal: (1) Description of the coverage aspects of descriptive notes conducted by the teacher on student report cards; (2) Description of the efforts of the teacher to make descriptive notes on student report cards; (3) Power encouragement of descriptive teacher notes on report cards against students.

Data on the three research objectives were extracted from 158 students, 143 parents, and 69 teachers.

1. Description of coverage aspects of descriptive notes that teachers do on student report cards.

To get information related to "aspects that are used as the basis of teacher's descriptive notes on student report cards", the same questions are asked to the teacher, students, and teachers about (a) aspects of what the teacher notes in the student report card, (b) matters are considered important in making descriptive notes on student report cards, and (c) the contents of the teacher's descriptive notes in student report cards.

Table 1: Percentage of Aspects of Teacher's Descriptive Notes on Student Report Cards According to Teachers, Parents, and Students

\begin{tabular}{cccc}
\hline $\begin{array}{c}\text { Note } \\
\text { Aspects }\end{array}$ & Teachers & Parents & Students \\
\hline Cognitive & 28 & 22 & 16 \\
Skill & 23 & 22 & 19 \\
Attitude & 35 & 27 & 23 \\
Total & 84 & 87 & 87 \\
Not know & 1 & 1 & 1 \\
\hline
\end{tabular}

For questions about "aspects recorded by teachers in student report cards", information was obtained that the teacher recorded were (a) knowledge (teacher 28\%, students $16 \%$, and parents 22\%), (b) skills (teacher 23\%, students $19 \%$, and parents 22\%), (c) attitudes (teachers $35 \%$, students $23 \%$, and parents $27 \%$ ), (d) do not know, filled in applications (teacher $1 \%$, students $1 \%$, and people $1 \%$ old). So, for this question information is obtained that there is a balance between knowledge, skills, and attitudes in the teacher's descriptive notes. Comparison of the proportion of aspects recorded by the teacher in student report cards, as illustrated in Graph 1 below. 


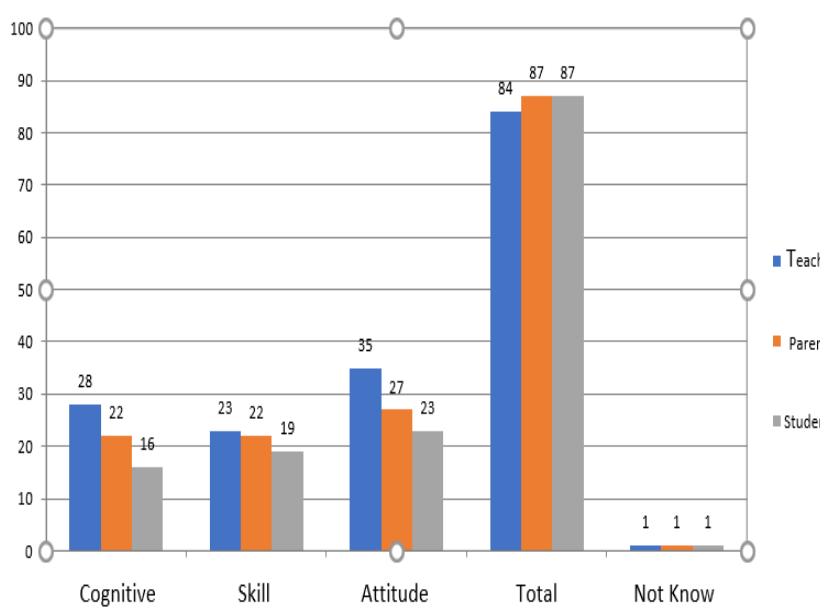

Graph 1: Aspects of teacher's descriptive notes on student report cards

Aspects that are considered important in making descriptive notes on student report cards are (a) writing / naming students (teacher $36 \%$, students $28 \%$, and parents $31 \%$ ), (b) mentioning student behavior (teacher $58 \%$, students $42 \%$, and $40 \%$ parents), (c) ways of completing assignments (73\% teachers, $29 \%$ students, and $33 \%$ parents), (d) student attitudes in class $(69 \%$ teachers, $21 \%$ students, and people old $20 \%$ ), (e) attendance of students (teacher $72 \%$, students $39 \%$, and parents 39\%), (f) congratulations on changes in student behavior (teacher $75 \%$, students $72 \%$, and parents $68 \%$ ), (g) avoid negative labels (83\% teachers, $70 \%$ students, and $68 \%$ parents), (i) write rescue words $(85 \%$ teachers, $77 \%$ students, and $76 \%$ parents). Of all respondents' answers, it was concluded that the most important thing to note in student report cards was "giving words of encouragement" and "student behavior". The aspect that gets the least attention is "mentioning the name of the student" in making notes.

The contents of the teacher's descriptive notes and respondents' assessments include (a) the achievement of learning outcomes that are complete and carried out by students (70\% teacher, $84 \%$ students, and $89 \%$ parents), (b) aspects that require a lot of help (19\% teacher, students $13 \%$, and $16 \%$ parents), (c) what students must do in improving learning outcomes (13\% teachers, $30 \%$ students, and $31 \%$ parents), and (d) answers do not know, because they are filled with computer applications (teacher $2 \%$, students $3 \%$, and parents $3 \%$ ). It can be concluded that the most important content in making descriptive notes is the achievement of learning outcomes that are complete and done by students, while the statement that the teacher does not know because it is filled with applications is only recognized by $3 \%$ of teachers.

2. Description of the efforts of the teacher to make descriptive notes on student report cards.

The teacher's attempt to make a descriptive note on the student report card is explored with questions (a) whether the teacher writes his own descriptive note on the student report card, (b) whether the student reads the teacher's notes on the report card, (c) whether the teacher's notes on student report cards are based on data comprehensive, (d) how the teacher views the task of writing descriptive notes on student report cards, (e) what is done before writing descriptive notes on student report cards. For questions, (a) whether the teacher wrote the descriptive note himself, $43 \%$ of the teachers stated their own writing and $55 \%$ said they did not write themselves. When viewed by the school, those who write themselves $0 \%$ in the Gembala baik High School, 46\% in the Senior High School, and $69 \%$ in the High School in the KKU. Conversely, $100 \%$ in Gembala baik High School said they did not write themselves, but used applications prepared by the school, $53 \%$ of teachers in Santun High School used the application, and 28\% in SMA in KKU who used the application. The answers given by students and parents are more confident that the teacher's notes are made by themselves (69\% students and $71 \%$ parents). The important thing that can be concluded is, in schools that have complete facilities such as Gembala baik High School, there is a tendency for descriptive note writing to use available applications.

The answer to the question about the teacher's beliefs whether students read and understand the notes was 30\% reading, 38\% understood, $46 \%$ were written according to students' problems, convinced $45 \%$ could encourage students, and $15 \%$ of teachers believed the notes made changes to students. Furthermore, whether the student report cards are made based on comprehensive data, $65 \%$ of teachers state "yes" and 35\% state that they use certain data. This answer is in line with students 'answers stating $46 \%$ of teachers' notes are "very focused" (52\% parents) and $47 \%$ "quite focused" (48\% parents).

For the question, "what is done before writing descriptive notes on student report cards" 
is stated by the teacher (1) to be positive and avoid negative labels on students (21\%), (2) believe that each student can change (21\%), (3) prepare student data $(17 \%)$, (4) pay attention to student anecdotal records (23\%), (5) discussions with colleagues (12\%, and declare "do not know" because there is an application (4\%). the teacher has done his job by considering the aspects needed.

Questions about, "how do teachers view the task of writing descriptive records on student report cards?" The teacher stated, must be in accordance with basic competencies $(51 \%)$, only $3 \%$ formality ( $5 \%$ in Gembala baik High School), troublesome teachers (1\%), a good thing because to encourage students (64\%), have succeeded in encouraging students (16\%), and those who answered "do not know" (3\%). So, according to the teacher's opinion "descriptive notes" on student report cards is a good thing, because it is intended to encourage students.

3. Power encouragement of teacher descriptive notes on report cards to students.

Answering the question about "do students apply teacher notes", the teacher answered "always" $10 \%$, "often" 41\%, "sometimes" 46\% (except for the Gembala baik High School, sometimes reaching $65 \%$ ). For the question of whether the teacher's descriptive notes have succeeded in "encouraging" students, the teacher said "quite enthusiastic" (54\%), except for the Gembala baik High School (65\%). Student and parent answers contradict the teacher's opinion. For descriptive notes it is stated "good, to encourage students". Only 10\% (8\% in Gembala baik High School, $10 \%$ in Senior High School, and 13\% in High School in KKU) said "successfully encouraging students". The rest of the students said "must be adjusted to the competencies of students" (54\%) and "only formalities" (10\%). According to $15 \%$ of students' parents, the teacher's descriptive notes succeeded in encouraging students. In general, both teachers, students, and parents require that the teacher's descriptive notes must be in accordance with the students' basic competencies. So, overall, according to students and parents, the teacher's descriptive notes "have not succeeded" in encouraging students.

\section{Discussion}

This discussion first looks at whether there are differences of opinion between students, teachers, and parents in the Gembala baik High
School ( $\mathrm{X}=$ respondents who represent schools with the category "A") with students, teachers, and parents of SMA Santun Untan, and ( $\mathrm{Y}=$ respondent who represent schools in the "B" category) and with students, teachers, and high school parents in Sukadana Kayong Utara (Z) as schools that represent districts are relatively "undeveloped" in their education. The difference test is done between $\mathrm{X}$ and $\mathrm{Y}$; between $\mathrm{X}$ and $\mathrm{Z}$, and between $\mathrm{Y}$ and $\mathrm{Z}$. For students, the value of

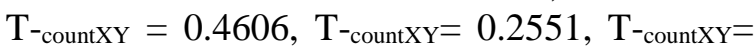
0.2247 , all smaller than $\mathrm{T}_{\text {table } 0.05}=1.684$. This means that there are no differences in the assessment of students from the three different schools in that category. This can be seen also from the average opinion of students from the three schools, which are almost the same, namely the Gembala baik High School 37.15, SMA Santun Untan 37.75, and SMA in Sukadana Kayong Utara 32.92. For parents of students, the value of $\mathrm{T}$ - -ountXY $=0.4304, \mathrm{~T}$ - countXY $=0.2885, \mathrm{~T}$ countXY $=0.2326$ all of which are smaller than $\mathrm{T}_{\text {tablea } 0.05}=1.684$. This means that there is no difference in the assessment of parents of students from the three different schools in that category against the teacher's descriptive notes on student report cards. This can be seen also from the average opinion of parents of the three schools almost the same, namely Gembala baik High School 37.31, Senior High School Santun Untan 38.42, and High School in Sukadana Kayong Utara 33.52.

To examine more deeply, researchers also saw whether there was a relationship between the assessment of students and parents in the three schools. It turned out that the calculation of $\mathrm{r}_{\mathrm{xy}}$ in the Gembala baik High School "was very high, which was $0.99, \mathrm{r}_{\mathrm{xy}}$ in Santun High School was" very high ", namely 0.97, and $r_{x y}$ at Sukadana High School KKU, which was 0.97 .

From the different test and test the relation between the assessment of students and parents (in the three schools) it can be concluded that the evaluation of the two groups of respondents was "compelling" to the descriptive notes made by the teacher on student report cards. This means that both individually (each school and each group of respondents) and together (combined) the assessment can be trusted.

Coverage aspects of teacher's descriptive notes on student report cards. The aspects recorded by the teacher in the student report card include knowledge, skills, and attitudes. Note that all three aspects are quite balanced. This 
means that the teacher pays attention to all aspects of the value that is in the student report card. In making note of the teacher paying attention, writing / mentioning the name of the student, student behavior, how to complete the assignment, the attitude of the students in the class, the presence of students, avoiding negative labels and writing the words of the savior. Of all respondents' answers, it was concluded that the most important thing to note in student report cards was "giving words of encouragement" and "student behavior". The aspect that gets the least attention is "mentioning the name of the student" in making notes. The contents of the teacher's descriptive notes include; achievement of student learning outcomes, aspects that require a lot of help, and efforts to improve learning outcomes. The most important content in making descriptive notes is the achievement of student learning outcomes. The information obtained is relevant to the opinion of Komarudin (2015) which states that the teacher's encouragement record on student report cards is sentences that encourage and explain that students have tried, and that process is recorded as a form of appreciation.

Description of the efforts of the teacher to make descriptive notes on student report cards. The most important thing expressed in this section is (a) whether the teacher writes his own descriptive note on the student report card, (b) whether the student reads the teacher's note on the report card, (c) does the teacher record on student report cards based on comprehensive data (d) how the teacher views the task of writing descriptive notes on student report cards, (e) what is done before writing descriptive notes on student report cards. From these questions it was revealed that some teachers $(43 \%)$ wrote their own descriptive notes on student report cards, while $55 \%$ did not write themselves, because computer applications were already available. Disappointing enough was information that only about one-third of students ability in reading and understanding teacher notes. Even only $15 \%$ of teachers believe students apply the notes made. However, most teachers said the note was good for encouraging students. This is in accordance with the opinion of (Canfield, 1990) which can be concluded that teacher's descriptive notes can encourage students in positive things.

The teacher's assessment method has described the aspects and stages of the assessment of attitudes, knowledge, and skills, namely (a) observing the behavior of students during learning, (b) recording the behavior of students using observation/ observation sheets, (c) following up on observations, and (d) describe the behavior of students (Permendikbud No. 23 of 2016, concerning Educational Assessment Standards). The important thing that must be considered by the teacher is that students are unique individuals, therefore the strengths and weaknesses of one another are not the same (Yigit, I. H., \& Tatch, 2017). Including the complexity of determining problems related to subject matter.

The encouragement power of teacher descriptive notes on report cards to students. The information revealed from the power of encouragement of the teacher's descriptive record is that only a small proportion of students and parents acknowledge that the descriptive notes made by the teacher can encourage students. In other words, according to students and parents the teacher's descriptive notes are ineffective or have not succeeded in encouraging students. This is different from the overall opinion of the teacher stating that the notes made can encourage students to improve learning outcomes, changes in attitudes, and behavior. The effectiveness requirements of the descriptive notes according to teachers, students, and parents is that the descriptive notes on report cards must be in accordance with the problems and characteristics of the individual students (Jacobs, 2012); (Walberg \& Greenberg, 1997).

\section{CONCLUSIONS AND SUGGESTIONS}

The aspects included in the descriptive notes made by the teacher on student report cards are knowledge, attitudes, and skills. These aspects are illustrated in the details of the teacher's descriptive notes including the mention of student names, behavior, how to complete tasks, attitudes, attendance, writing congratulations on changing student behavior, avoiding negative labels, and writing encouraging words. About the contents of the teacher's descriptive notes, consisting of the achievement of complete learning outcomes and the things students must do. In making descriptivenotesthere are some teachers who write themselves and others use computer application facilities at school. From the notes made, it turns out that one-third of students in ability reading and understanding teacher's notes. 
This is in line with the teacher's opinion stating that only a small percentage of students apply the notes made. However, most teachers said the note was good for encouraging students. Power encouragement of descriptive records of teachers recognized by students and parents has not been effective and has not been able to encourage students. In other words, according to students and parents the teacher's descriptive notes are ineffective or have not succeeded in encouraging students.

Based on the results of the research that has been done, the teacher was advised when making descriptive notes that the teacher used comprehensive data, avoided negative labels, enriched and used different vocabulary that could encourage students, paid attention to students' uniqueness, and paid attention to cases that really faced by students.

\section{REFERENCE}

Abrar, M., Mukminin, A., Habibi, A., Asyrafi, F., Makmur, M., \& Marzulina, L. (2018). "If our English isn't a language, what is it?" Indonesian EFL Teachers' Challenges Speaking English. The Qualitative Report, 23(1), 129-145. Retrieved from https://nsuworks.nova.edu/tqr/vol23/iss1/9

Astuti, I. (2015). Pengembangan Model Pembelajaran Konseling Kelompok Konstruktivistik, 2015. Disertasi (tidak beredar), Jakarta: UNJ. Universitas Negeri Jakarta.

Baird, K., Gamble, J., \& Sidebotham, M. (2016). Assessment of the quality and applicability of an e-portfolio capstone assessment item within a bachelor of midwifery program. Nurse Education in Practice, 20, 11-16. https://doi.org/10.1016/j.nepr.2016.06.007

Belland, B. R., Walker, A. E., Olsen, M. W., \& Leary, H. (2015). A pilot meta-analysis of computer-based scaffolding in STEM education. Educational Technology \& Society, 18(1), 183-197.

Belland, B. R. (2014). Scaffolding: Definition, current debates, and future directions. In J. M. Spector, et al. (Eds.), Handbook of research on educational communications and technology. New York: Springer.

Canfield, J. (1990). Improving students' selfesteem. Educational Leadership, 48(1), 4850.

Ceka, Ardita \& Murati, R. (2016). The Role of Parents in the Education of Children.
Journal of Education and Practice, 7(5).

Claessens, L., van Tartwijk, J., Pennings, H., van der Want, A., Verloop, N., den Brok, P., \& Wubbels, T. (2016). Beginning and experienced secondary school teachers' self- and student schema in positive and problematic teacher-student relationships. Teaching and Teacher Education, 55, 8899.

https://doi.org/10.1016/j.tate.2015.12.006

Corey, G. (2011). Group Prosess and Practice. Australia: Thomson Brooks/Cole.

Dalman. (2015). Menulis karya ilmiah. Depok: Rajagrafindo Persada.

Depdiknas. (2000). Kamus Besar Bahasa Indonesia. Jakarta: Gramedia Pustaka Cipta.

Hagenauer, G., Hascher, T., \& Volet, S. E. (2015). Teacher emotions in the classroom: associations with students' engagement, classroom discipline and the interpersonal teacher-student relationship. European Journal of Psychology of Education, 30(4), 385-403. https://doi.org/10.1007/s10212015-0250-0

Hornby, A. S. (1995). Oxford Advanced Learner's Dictionary. Oxford: Oxford University Press.

Jacobs, E. E. E. al. (2012). Group Counseling :Strategy and Skills. California: Brook/Cole Publishing Company.

James. (2010). Parenting Educational For Empowering Parent in The Holistic Development of Children in Indonesia. Jakarta: Yayasanindo Collaboration with LTC.

Joyce, H. D., \& Early, T. J. (2014). The impact of school connectedness and teacher support on depressive symptoms in adolescents: A multilevel analysis. Children and Youth Services Review, 39, 101-107. https://doi.org/10.1016/j.childyouth.2014.0 2.005

Komarudin, U. (2015). Arief rachman Guru. Jakarta: Erlangga.

Lin, T. C., Hsu, Y. S., Lin, S. S., Changlai, M. L., Yang, K. Y., \& Lai, T. L. (2012). A review of empirical evidence on scaffolding for science education. International Journal of Science and Mathematics Education, 10(2), 437-455.

Maslow, A. H. (2013). A theory of human motivation. New York: Simon and Schuster.

Megawangi, R. (2004). Pendidikan karakter: 
Solusi yang tepat untuk Membangun Bangsa. Jakarta: Star Energy.

Michelle, G. J. G. W. \&Colla. (2001). Designing For Leraning Six in Coctructivist Classrooms. California: Corein Press, Inc.

Mona, M. (2012). Just The Right Words. A Journal Of Learning Journey (vol 1-6). New York: New York.

Nicol, D. (2010). From monologue to dialogue: Improving written feedback processes in mass higher education. Assessment and Evaluation in Higher Education, 35(5), 501-517.

https://doi.org/10.1080/026029310037865 59

Panjaitan, S. C. Y. S. dan K. (2015). Pengaruh Strategi Pembelajaran dan Locus of Control terhadap Hasil Belajar. Jurnal Teknologi Pendidikan, 8(2).
Povey, J., Campbell, A. K., Willis, L. D., Haynes, M., Western, M., Bennett, S., ... Pedde, C. (2016). Engaging parents in schools and building parent-school partnerships: The role of school and parent organisation leadership. International Journal of Educational Research, 79, 128-141. https://doi.org/10.1016/j.ijer.2016.07.005

Prawiradilaga, D. S. et al. (2004). Mozaik Teknologi Pendidikan. Jakarta: Prenada Media group.

Pribadi, B. A. (2018). Konsep Esensial Teknologi Pendidikan. Jakarta: Dian Rakyat.

Walberg \& Greenberg. (1997). Using the Learning Environment Inventory. Educational Leadership, 54(8).

Yigit, I. H., \& Tatch, A. (2017). Syrian refugees and Americans: Perceptions, attitudes and insights. American Journal of Qualitative Research, 1(1), 13-31. 